\title{
DŁUG PUBLICZNY W UJĘCIU EKONOMICZNYM I PRAWNYM. ZMIENNOŚĆ DŁUGU PUBLICZNEGO W WYBRANYCH GOSPODARKACH POZAEUROPEJSKICH PO 2007 ROKU NA TLE PAŃSTW UNII EUROPEJSKIEJ
}

\section{Wprowadzenie}

W przygotowaniu niniejszego artykułu przyświecały mi dwa zasadnicze cele.

Pierwszym z nich było dokonanie analizy porównawczej kilku najważniejszych prawnych metodologii definiowania (obliczania) długu publicznego opracowanych przez organizacje międzynarodowe. Inspiracją do przeprowadzenia tej analizy był fakt, że w ostatnim czasie przedstawiono nowe wersje dwóch z tych metodologii i niebawem staną się one obowiązujące dla krajów, których dotyczą. Przedstawiłem także polską prawną metodologię liczenia długu publicznego, wskazując na różnicę między nią a metodologiami międzynarodowymi. Wprowadzeniem do prezentacji prawnego ujęcia długu publicznego było pokazanie, jak pojęcia deficytu budżetowego i długu publicznego ujmowane są przez teorię ekonomii.

W drugiej części artykułu przeanalizowałem zmienność deficytu ekonomicznego budżetu państwa i długu publicznego w wybranych gospodarkach pozaeuropejskich po 2007 r., a zatem w okresie określanym jako lata światowego kryzysu finansowo-gospodarczego. Pod uwagę wziąłem te kraje z poszczególnych kontynentów, które są w grupie 60 największych gospodarek świata według kryterium PKB w cenach rynkowych według parytetu siły nabywczej. Sytuację finansów publicznych gospodarek pozaeuropejskich w ostatnich latach przedstawiłem na tle stanu finansów publicznych krajów Unii Europejskiej. Analizie zmienności deficytu budżetowego i długu publicznego po 2007 r. w krajach UE poświęciłem wiele opracowań z lat wcześniejszych. W tym artykule uaktualniłem tę analizę o rok 2013.

Analizy stanu finansów publicznych krajów pozaeuropejskich zostały przeprowadzone w oparciu o dane Banku Światowego (uzyskane według metodologii SNA 93), a stanu finansów publicznych gospodarek europejskich na podstawie danych Eurostatu (uzyskanych w oparciu o metodologię według kryteriów z Maastrich, tzw. metodę EDP). 


\section{Dług publiczny w ekonomii}

W ekonomii dług publiczny definiuje się jako sumę wszystkich zobowiązań państwa na dany moment. Dług publiczny policzony na koniec roku t pokazuje, jakie są łączne zobowiązania państwa na koniec roku t, z kolei wynik ekonomiczny budżetu państwa w roku t (czyli wynik, który zgodnie z teorią ekonomii najlepiej odzwierciedla stan finansów publicznych państwa w danym roku) pokazuje, jak te zobowiązania zmieniły się w roku t. Jeżeli w danym kraju w roku t budżet państwa zamknął się wysokim deficytem ekonomicznym, to nie znaczy automatycznie, że należy negatywnie ocenić sytuację finansów publicznych. W kraju tym możemy mieć bowiem do czynienia z niskim długiem publicznym, co znaczy, że jest tam przestrzeń dla wysokich deficytów budżetowych przez jakiś czas.

Formuła ekonomicznego wyniku budżetu państwa prezentowana w podręcznikach makroekonomii ma następującą postać:

$$
\begin{gathered}
\text { WYNIK EKONOMICZNY BUDŻETU PAŃSTWA }(\mathbf{t}) \\
=[\text { DOCHODY KASOWE }(\mathrm{t})+\Delta \text { NALEŻNOŚCI PAŃSTWA }(\mathrm{t})] \\
-[\text { WYDATKI KASOWE }(\mathrm{t})+\Delta \text { ZOBOWIĄZAŃ WYMAGALNYCH } \\
\text { PAŃSTWA } \left.(\mathrm{t})^{\mathrm{a}}\right]
\end{gathered}
$$

Po przekształceniach:

$$
\begin{gathered}
\text { WYNIK EKONOMICZNY BUDŻETU PAŃSTWA }(\mathrm{t}) \\
=\text { WYNIK KASOWY BUDŻETU PAŃSTWA }(\mathrm{t})+ \\
+\Delta \text { NALEŻNOŚCI PAŃSTWA }(\mathrm{t})- \\
\begin{array}{c}
\Delta \text { ZOBOWIĄZAŃ WYMAGALNYCH PAŃSTWA }(\mathrm{t})^{\mathrm{a}}
\end{array}
\end{gathered}
$$

${ }^{a}$ Chodzi o przyrost zobowiązań wymagalnych państwa wyłącznie z tytułu niezapłacenia za otrzymane produkty
oraz niewypłacenia transferów, których wypłacenie ciążyło na państwie.

W literaturze ekonomii i finansów publicznych pojawiają się też takie pojęcia, jak potencjalny dług publiczny i ukryty dług publiczny. Potencjalny dług publiczny to zobowiązania państwa (wynikające $\mathrm{z}$ aktów prawnych, zawartych umów), których wysokość trudno jest określić i których zapadalność wiąże się z wystąpieniem konkretnego zdarzenia (którego wystąpienie nie jest zresztą pewne). Zobowiązaniem takim są np. udzielone przez państwo gwarancje i poręczenia czy też zobowiązania związane $\mathrm{z}$ reprywatyzacją ${ }^{1}$.

1 K. Marchewka-Bartkowiak, Zarzadzanie długiem publicznym, PWN, Warszawa 2008, s. 187. 
Z kolei pojęcie ukrytego długu publicznego pojawiło się w związku z tym, że w coraz większej liczbie krajów (dotyczy to zwłaszcza Europy) zachodzą niekorzystne dla publicznych systemów emerytalnych zmiany demograficzne. Sumę przewidywanych na przyszłe okresy wypłat świadczeń emerytalnych należnym osobom uczestniczącym w systemie emerytalnym określa się właśnie jako ukryty dług publiczny².

\section{Analiza porównawcza prawnych metodologii liczenia długu publicznego}

Prezentowane w ekonomii i finansach publicznych definicje kategorii obrazujących sytuację finansów publicznych wymagają doprecyzowania, jeżeli chcemy je zastosować do prezentacji stanu tych finansów w konkretnym kraju. Definiując w prawie deficyt budżetowy czy dług publiczny, powinno się pamiętać o tym, aby nie utracić ekonomicznej istoty tych kategorii.

Metodologie liczenia wyniku budżetowego i długu publicznego tworzą w ramach swojego ustawodawstwa poszczególne kraje, a także organizacje międzynarodowe. Kraje, które są członkami tych organizacji, mają obowiązek prezentować sytuację swoich finansów publicznych także na podstawie ich metodologii. Metodologie międzynarodowe są opracowywane m.in. po to, aby sytuacja budżetowa (wskaźniki obrazujące kondycję finansów publicznych są jednymi z istotniejszych wskaźników ilustrujących sytuacje makroekonomiczną danej gospodarki) danego kraju była przejrzysta dla otoczenia (co jest bardzo ważne w warunkach postępującego procesu globalizacji gospodarki) i na potrzeby międzynarodowych analiz porównawczych. Innym powodem tworzenia metodologii międzynarodowych jest chęć opracowywania na ich podstawie kryteriów, jakie musi spełnić jakaś grupa krajów w zakresie poziomu deficytu budżetowego czy długu publicznego. Z taką sytuacją mamy do czynienia w odniesieniu do krajów, które są członkami strefy euro, bądź zobowiązały się do przystąpienia do tej strefy w przyszłości.

Poniżej omówiłem, w ujęciu porównawczym, sposób kalkulowania długu publicznego zgodnie z takimi metodologiami, jak: System Rachunków Narodowych (SNA 93), Europejski System Rachunków Narodowych i Regionalnych (ESA 95 i ESA 2010) oraz zgodnie z kryteriami z Maastricht (EDP). Przedstawiłem także polską metodologię (zawartą w obowiązującej aktualnie ustawie o finansach publicznych) i porównałem ją z metodologiami międzynarodowymi, zwłaszcza z metodologią EDP.

2 M. Góra, System emerytalny, Oficyna Wydawnicza SGH, Warszawa 2003. 


\subsection{System Rachunków Narodowych (SNA 93)}

Metodologia SNA 93 została w 1993 r. wspólnie opracowana i opublikowana przez Departament Statystyki ONZ, Eurostat (biuro statystyki Komisji Europejskiej Unii Europejskiej), Międzynarodowy Fundusz Walutowy (MFW), Organizację Współpracy Gospodarczej i Rozwoju (OECD) oraz Bank Światowy. SNA 93 zawiera metody wyliczania wielu wskaźników makroekonomicznych. Część dotycząca metodologii prezentacji stanu finansów publicznych jest publikowana przez MFW w „Podręczniku Statystyki Finansów Władz Publicznych". Metodologia prezentacji stanu finansów publicznych oparta na SNA 93 określana jest metodą GFSM01. Do pokazywania sytuacji finansów publicznych według tej metody zobowiązane są kraje członkowskie Międzynarodowego Funduszu Walutowego. Wskaźniki obrazujące sytuację budżetu państwa wyliczone w oparciu o SNA 93 publikują takie organizacje, jak: MFW, Bank Światowy, ONZ i OECD.

Szczegóły tej metodologii zostały przedstawione w punkcie 2.2. Z jego treści wynika też, dlaczego tak uczyniłem.

\subsection{Europejski System Rachunków Narodowych i Regionalnych (ESA 95) ${ }^{3}$}

Metodologia ta została opracowana przez Eurostat i zaakceptowana przez Komisję Europejską. Moc prawną uzyskała jako załącznik do rozporządzenia Rady nr 2223/96 w sprawie europejskiego systemu rachunków narodowych i regionalnych we Wspólnocie. Do prezentacji stanu finansów publicznych według metody ESA 95 zobowiązane są kraje należące do Unii Europejskiej (na potrzeby Eurostatu). Metodologia ESA 95 także nie dotyczy tylko finansów publicznych, ale określa sposób liczenia innych kategorii makroekonomicznych.

Należy podkreślić, że różnice w liczeniu długu publicznego między metodologiami SNA 93 i ESA 95 nie są duże. Dlatego często są one traktowana jako jedna metoda.

Zakres podmiotowy i przedmiotowy długu publicznego według SNA 93 i ESA 95 jest niemal identyczny. Ponadto obydwie metodologie w sprawozdawczości finansowej przyjmują bazę memoriałową, a nie kasową, tzn. wartość zobowiązań jest obliczana według momentu ich powstania, a nie momentu wpływu albo wypływu środków pieniężnych. Zarówno w jednej, jak i drugiej metodzie zadłużenie ujmuje się według wartości rynkowych, a nie nominalnych.

3 Na podstawie: ESA 95 manual on government deficyt and debt, Office for Official Publications of the European Communities, Luxemburg 2002 oraz Government Finance Statistics Manual 2013, International Monetary Fund, Washington. 
Zakres podmiotowy długu publicznego wynika ze zdefiniowania sektora finansów publicznych. Zgodnie z obiema omawianymi metodologiami sektor finansów publicznych obejmuje wszystkie jednostki instytucjonalne, które działają na zasadach nierynkowych, a efekty ich działalności są przeznaczone do spożycia indywidualnego oraz zbiorowego, i które są finansowane głównie z obowiązkowych świadczeń przekazywanych przez jednostki innych sektorów i/lub wszystkie jednostki instytucjonalne, których podstawowym zadaniem jest redystrybucja dochodu narodowego.

Według SNA 93 oraz ESA 95 jednostkami instytucjonalnymi sektora finansów publicznych są:

1) jednostki władz publicznych (z wyłączeniem publicznych spółek i innych osób prawnych zaliczonych do sektora przedsiębiorstw albo sektora instytucji finansowych), które administrują i finansują grupę działalności polegających głównie na dostarczaniu nierynkowych dóbr i usług przeznaczonych na zaspokojenie potrzeb społeczeństwa;

2) instytucje niekomercyjne, uznane za osoby prawne, które działają na zasadach nierynkowych oraz są kontrolowane i głównie finansowane przez władze publiczne; 3) autonomiczne fundusze emerytalne.

Według SNA 93 oraz ESA 95 sektor finansów publicznych składa się z następujących podsektorów:

a) Podsektor centralnych finansów publicznych obejmuje wszystkie jednostki administracyjne i inne instytucje centralne, których kompetencje rozciągają się z zasady na całe terytorium gospodarcze podległe tym władzom, $\mathrm{z}$ wyjątkiem zarządzania funduszami zabezpieczenia społecznego. Do tego podsektora należą te niekomercyjne instytucje, które są kontrolowane i głównie finansowane przez centralne władze publiczne, i których kompetencje obejmują to samo terytorium.

b) Podsektor lokalnych finansów publicznych obejmuje te rodzaje instytucji publicznych, których kompetencje rozciągają się jedynie na lokalny obszar gospodarczy, z wyjątkiem lokalnych oddziałów funduszy zabezpieczenia społecznego. Do tego podsektora należą te niekomercyjne instytucje, które są kontrolowane i głównie finansowane przez lokalne władze publiczne, i których kompetencje są ograniczone do obszaru działania władz lokalnych.

c) Podsektor władz publicznych państw sfederowanych obejmuje odrębne jednostki instytucjonalne pełniące funkcje władz publicznych o szczebel niższe niż władze centralne i szczebel wyższe niż jednostki instytucjonalne władz lokalnych, z wyjątkiem zarządzania funduszami zabezpieczenia społecznego. Do tego podsektora należą te niekomercyjne instytucje, które są kontrolowane i głównie finansowane przez władze publiczne państw sfederowanych, i których kompetencje rozciągają się na obszar gospodarczy tych państw. 
d) Podsektor funduszy zabezpieczenia społecznego obejmuje wszystkie centralne i lokalne jednostki instytucjonalne, których podstawowa działalność polega na dostarczaniu świadczeń społecznych, i które spełniają następujące kryteria:

- określone grupy ludności są zobowiązane prawnie do udziału w programie lub do opłacania składek,

- władze publiczne są odpowiedzialne za zarządzanie instytucją pod względem ustalania lub zatwierdzania wysokości składek ubezpieczeniowych i świadczeń, niezależnie od ich roli jako organu nadzorującego albo jako pracodawcy.

W SNA 93 i ESA 95 zaznacza się, że dług publiczny odnosi się tylko do zadłużenia podmiotów sektora finansów publicznych, a nie do zadłużenia całego sektora publicznego. W skład sektora publicznego wchodzą, obok sektora finansów publicznych, także przedsiębiorstwa publiczne i banki publiczne, które są jednostkami samofinansującymi się. Utrzymują się one z działalności komercyjnej, a nie z funduszy publicznych, a nawet powiększają te fundusze poprzez wpłaty do budżetu podatków, części zysków czy dywidendy.

W metodologii ESA 95 zakres przedmiotowy długu publicznego został określony poprzez wymienienie rodzajów zobowiązań. Wielkość długu publicznego jest równa sumie wszystkich zobowiązań sektora finansów publicznych w kategoriach: gotówka i przyjęte depozyty, papiery wartościowe inne niż udziały łącznie z finansowymi instrumentami pochodnymi, pożyczki i inne rachunki wymagalne (kredyty handlowe, zobowiązania z tytułu nadpłaconych podatków, niezrealizowanych świadczeń z ubezpieczeń społecznych i wynagrodzeń, nieopłaconej dzierżawy, zaległości w spłacie oprocentowania długu), a także w niektórych przypadkach występujące w małej skali udziały i inne akcje oraz rezerwy techniczno-ubezpieczeniowe.

Z niemal identycznym zakresem przedmiotowym długu publicznego mamy do czynienia w metodologii SNA 93. Jedynym wyjątkiem jest to, że według SNA 93 do długu publicznego nie wlicza się instrumentów pochodnych.

\subsection{Metodologia liczenia długu publicznego według kryterium z Maastricht ${ }^{4}$}

Ta metoda jest oficjalnie nazywana definicją długu publicznego według „procedury nadmiernego deficytu” („excessive deficit procedure”), w skrócie EDP. Na podstawie poziomu długu publicznego obliczonego właśnie tą metodą określa się, czy

4 Na podstawie rozporządzenia Rady Unii Europejskiej o stosowaniu protokołu w sprawie procedury dotyczącej nadmiernego deficytu nr 479/2009 z 25 maja 2009 r. dołączonego do Traktatu ustanawiającego Wspólnotę Europejską. 
państwa członkowskie i kandydujące do Unii Gospodarczej i Walutowej spełniają kryterium długu publicznego (60,0\% PKB) zawarte w Traktacie ustanawiającym Wspólnotę Europejską. Aktualna wersja tej metodologii jest zawarta w rozporządzeniu Rady Unii Europejskiej o stosowaniu protokołu w sprawie procedury dotyczącej nadmiernego deficytu nr 479/2009 z 25 maja 2009 r. dołączonego do Traktatu ustanawiającego Wspólnotę Europejską.

Ta metodologia różni się od metodologii ESA 95 zakresem zobowiązań państwa branych pod uwage przy obliczaniu poziomu długu publicznego. Obecnie Eurostat w swoich publikacjach przedstawia tylko te dane o poziomie długu publicznego, które są obliczone zgodnie $\mathrm{z}$ tą metodologią.

Zakres podmiotowy długu publicznego według kryterium z Maastricht jest identyczny jak w metodologiach ESA 95 i SNA 93. Różnice występują natomiast, jeśli chodzi o zakres przedmiotowy długu publicznego. Według kryterium z Maastricht zakres przedmiotowy długu publicznego jest węższy. Wielkość długu publicznego jest tu równa sumie wszystkich zobowiązań sektora finansów publicznych w kategoriach: gotówka i przyjęte depozyty, papiery wartościowe inne niż udziały z wyjątkiem finansowych instrumentów pochodnych oraz pożyczki. Do długu publicznego według kryterium z Maastricht nie wlicza się zatem finansowych instrumentów pochodnych, rachunków wymagalnych, udziałów i innych akcji oraz rezerw techniczno-ubezpieczeniowych.

Jak pokazuje praktyka, różnica między długiem publicznym wyliczonym według metodologii ESA 95 (SNA 93) a długiem publicznym wyliczonym według kryterium z Maastricht $\mathrm{w}$ największym stopniu jest determinowana przez fakt niezaliczania, przez metodologię według kryterium z Maastricht, do długu publicznego rachunków wymagalnych (szczegółowe elementy tej kategorii wymieniono powyżej).

Zarówno metodologie ESA 95 i SNA 93, jak i metodologia według kryterium z Maastricht nie zaliczają do długu publicznego udzielonych przez sektor finansów publicznych gwarancji i poręczeń.

Zgodnie z kryterium z Maastricht dług publiczny jest obliczany według wartości nominalnych, a nie według wartości rynkowych (jak było to w metodologiach ESA 95 i SNA 93). Wartość nominalna zobowiązania jest rozumiana jako kwota świadczenia głównego, należna do zapłaty w dniu wymagalności zobowiązania. Natomiast według metodologii ESA 95 i SNA 93 do długu publicznego dodaje się naliczone memoriałowo, a jeszcze nieuregulowane kasowo odsetki od zobowiązań zaliczonych do długu (np. oprocentowanie wyemitowanych przez państwo obligacji).

We wszystkich przedstawionych metodologiach dług publiczny to dług brutto oraz dług skonsolidowany. Dług brutto to zadłużenie, które nie jest pomniejszone o należności sektora finansów publicznych (np. z tytułu niezapłaconych podatków), jak ma to miejsce w przypadku długu w ujęciu netto. Z kolei dług skonsolidowany 
to taki, przy którego liczeniu pomija się zadłużenia wobec siebie jednostek instytucjonalnych należących do sektora finansów publicznych ${ }^{5}$.

\subsection{Metodologia krajowa liczenia długu publicznego wynikająca z ustawy o finansach publicznych z dnia 27 sierpnia 2009 r.}

Kraje zobowiązane do prezentacji sytuacji sektora finansów publicznych według wymienionych metodologii mogą przedstawiać stan tych finansów także według własnej, krajowej metodologii. Administracja rządowa w Polsce stosuje krajową metodologię przedstawiania stanu finansów publicznych na potrzeby rozliczania się ze stanu tych finansów wobec Sejmu RP.

Szczególnie istotne jest zwrócenie uwagi na różnice pomiędzy polską metodologią liczenia długu publicznego a metodologią według kryterium z Maastricht. Jak bowiem wspomniano, to na podstawie poziomu długu publicznego obliczonego metodą EDP określa się, czy państwa członkowskie i kandydujące do Unii Gospodarczej i Walutowej spełniają kryterium długu publicznego określone w Traktacie ustanawiającym Wspólnotę Europejską.

Zakres podmiotowy długu publicznego według polskiej metodologii jest bardzo zbliżony do tego zakresu we wcześniej wymienionych metodologiach. Jedna z różnic polega na tym, że zgodnie z ESA 95 oraz metodą EDP (w interpretacji Eurostatu) do sektora finansów publicznych nie są zaliczane Polska Agencja Żeglugi Powietrznej oraz Polski Klub Wyścigów Konnych, które z kolei według polskiej metodologii stanowią elementy tego sektora. Ponadto według metodologii ESA 95 do sektora finansów publicznych zalicza się Krajowy Fundusz Drogowy i Fundusz Kolejowy, których ustawa o finansach publicznych nie traktuje jako części sektora finansów publicznych. Biorąc pod uwagę wielkość poziomu długu publicznego, szczególne znaczenie ma różnica w traktowaniu Krajowego Funduszu Drogowego ze względu na znaczną skalę jego zadłużenia 6 .

Zgodnie z metodologią polską dług publiczny jest obliczany według wartości nominalnych, a nie według wartości rynkowych, a zatem identycznie jak w przypadku metodologii według kryterium z Maastricht, a inaczej niż według metod ESA 95 i SNA 93.

Między metodologią polską a metodologią według kryterium z Maastricht istnieją różnice pod względem zakresu przedmiotowego długu publicznego. Zgodnie z polską

5 A. Wernik, Problemy definicji długu publicznego, „Studia Biura Analiz Sejmowych” nr 4(28), 2011, s. 13.

6 Ibidem, s. 12. 
metodologią do długu publicznego wlicza się?: wyemitowane papiery wartościowe opiewające na wierzytelności pieniężne, zaciągnięte kredyty i pożyczki, przyjęte depozyty, wymagalne zobowiązania wynikające z odrębnych ustaw oraz prawomocnych orzeczeń sądów lub ostatecznych decyzji administracyjnych, wymagalne zobowiązania uznane za bezsporne przez właściwą jednostkę sektora finansów publicznych będącą dłużnikiem. Zgodnie z metodologią według kryterium z Maastricht nie wlicza się natomiast, jak omówiono powyżej, rachunków wymagalnych.

\subsection{Nowe wersje metodologii ESA 95 i SNA 93}

Niebawem zaczną obowiązywać uaktualnione wersje metodologii ESA 95 i SNA 93. Będą one miały oznaczenia odpowiednio ESA 2010 i SNA 2008. W ciągu ostatnich lat zaszły znaczące zmiany, mające wpływ na gospodarkę. Zmiany te wymagają dostosowania metod opracowywania statystyk międzynarodowych. Nie stanowią one rewolucji, a jedynie korektę. $\mathrm{W}$ ramach tych zmian dokonano także pewnych korekt w zakresie liczenia poziomu deficytu ekonomicznego budżetu państwa i długu publicznego. Kraje UE będą musiały zastosować metodologię ESA 2010 już do prezentacji stanu finansów publicznych w 2014 r. USA wdrożyły z kolei metodologię SNA 2008 już w 2013 r. Niedługo według tej metodologii sytuację budżetową będą musiały pokazywać wszystkie kraje należące do Międzynarodowego Funduszu Walutowego.

W obydwu metodologiach zmiana w zakresie finansów publicznych polega na tym, że jako dochodu ekonomicznego budżetu państwa nie będzie można traktować pozycji, która rodzi jednocześnie wzrost zobowiązań państwa. Taka pozycja nie będzie mogła zatem poprawić wyniku ekonomicznego budżetu państwa, ani zmniejszyć poziomu długu publicznego. Ta zmiana ma szczególne znaczenie dla Polski w 2014 r. Przykładem pozycji, której dotyczy ta zmiana, jest umorzenie przez państwo w Polsce w 2014 r. części jego długu zaciągniętego (poprzez sprzedaż im skarbowych papierów wartościowych) w otwartych funduszach emerytalnych. Zgodnie z metodologią ESA 2010 o kwotę tego umorzenia nie będzie można ani zmniejszyć deficytu ekonomicznego budżetu państwa w 2014 r., ani zmniejszyć długu publicznego (na takie zabiegi pozwalała natomiast metodologia ESA 95). Powodem jest to, że rząd zobowiązał się do zapisania tej kwoty na specjalnych subkontach (w ZUS) osób, które płaciły składki emerytalne do otwartych funduszy emerytalnych, i wypłaty jej w przyszłości w formie świadczeń emerytalnych (kwota ta ma być ponadto dziedziczona podobnie jak środki wpłacane do OFE). Umorzenie to zatem rodzi zobowiązania

\footnotetext{
7 Art. 72 ustawy o finansach publicznych z dnia 27 sierpnia $2009 \mathrm{r}$.
} 
państwa, co powoduje, że nie będzie miało wpływu na poziom deficytu ekonomicznego budżetu państwa w 2014 r. i poziom długu publicznego na koniec 2014 r. wyliczonych metodologią ESA 2010. Zgodnie z tą metodologią pozytywny wpływ tego umorzenia na poziom deficytu budżetowego i długu publicznego będzie polegał tylko na tym, że od kwoty tego umorzenia państwo nie będzie musiało już ponosić kosztów obsługi długu publicznego.

\section{Zmienność deficytu ekonomicznego budżetu państwa i długu publicznego w państwach Unii Europejskiej po 2007 roku}

Zanim przystąpimy do analizy zmienności stanu finansów publicznych w wybranych gospodarkach nienależących do Unii Europejskiej, warto przypomnieć, jak i dlaczego w latach 2008-2013 zmieniał się wynik ekonomiczny budżetu państwa oraz dług publiczny w krajach Unii Europejskiej. Analizę tę przeprowadziłem m.in. w artykule Analiza porównawcza zmian deficytu ekonomicznego budżetu państwa i dtugu publicznego w państwach Unii Europejskiej w latach 2008-2012 opublikowanym w książce Wspótczesne państwo a dlug publiczny. Dylematy i mity (red. I. Zawiślińska, Oficyna Wydawnicza SGH, Warszawa 2014). Poniżej zaprezentowałem najistotniejsze wnioski z tych badań i uzupełniłem je wnioskami z analizy okresu (rok 2013), którego poprzednie opracowania nie obejmowały.

Lata 2008-2009 to okres powszechnego wzrostu deficytu ekonomicznego jako $\% \mathrm{PKB}^{8}$ w krajach Unii Europejskiej. Jedynym krajem, który zanotował w tym czasie poprawę wyniku ekonomicznego w relacji do PKB, były Węgry. W większości państw jedynym bądź głównym źródłem pogorszenia się wyniku ekonomicznego jako \% PKB był wzrost udziału wydatków budżetowych w PKB. Z kolei za wzrost wydatków budżetowych w relacji do PKB odpowiadał głównie wzrost nominalnych wydatków budżetowych, a nie zmniejszenie nominalnego PKB. Przyczyną pogorszenia się stanu finansów publicznych w latach 2008-2009 w większości krajów UE była zatem polityka budżetowa, a nie recesja gospodarcza.

W okresie 2008-2009 tylko w Bułgarii jedyną przyczyną wzrostu deficytu budżetowego jako \% PKB było zmniejszenie dochodów budżetowych w relacji do PKB. Spadek ten był efektem obniżenia stawek niektórych podatków. W Polsce, w Hiszpanii i na Cyprze wzrost wydatków budżetowych jako \% PKB oraz spadek dochodów

8 Chodzi o produkt krajowy brutto w cenach rynkowych. 
budżetowych jako \% PKB były równie istotnymi źródłami wzrostu deficytu ekonomicznego budżetu państwa w relacji do PKB.

Lata 2008-2009 to czas wzrostu długu publicznego we wszystkich krajach UE, z wyjątkiem Cypru.

Okres 2010-2011 przyniósł z kolei w większości krajów Unii Europejskiej redukcję deficytu ekonomicznego budżetu państwa w relacji do PKB. W tym czasie pogłębienie tego deficytu nastąpiło jedynie w Słowenii i na Cyprze. W 15 krajach spośród tych, w których zmniejszył się deficyt budżetowy, jedyną bądź główną determinantą tego zjawiska było zmniejszenie wydatków budżetowych jako \% PKB. Niestety, aż w 9 krajach redukcja wydatków budżetowych w relacji do PKB była spowodowana jedynie wzrostem nominalnego PKB, a więc poprawą koniunktury gospodarczej. Tylko w 6 krajach do obniżenia udziału wydatków budżetowych w PKB przyczyniło się zmniejszenie nominalnych wydatków budżetowych, a więc polityka budżetowa. W Polsce, Czechach, Grecji, Francji i na Malcie do zmniejszenia deficytu ekonomicznego budżetu państwa jako \% PKB w podobnym stopniu przyczyniły się spadek wydatków budżetowych jako \% PKB i wzrost udziału dochodów budżetowych w PKB. W większości tych krajów (także w Polsce) zmniejszenie udziału wydatków budżetowych w PKB osiągnięto jedynie dzięki wzrostowi nominalnego PKB. Tylko w Grecji determinantą spadku wydatków budżetowych jako \% PKB było zmniejszenie nominalnych wydatków budżetowych. W 5 państwach (Belgia, Dania, Portugalia, Irlandia, Węgry) jedynym źródłem poprawy wyniku ekonomicznego budżetu państwa jako \% PKB był wzrost udziału dochodów budżetowych w relacji do PKB (osiągnięty dzięki wzrostowi nominalnego $\mathrm{PKB}^{9}$, a w niektórych z tych państw także poprzez wzrost obciążeń podatkowych).

Mimo że w latach 2010-2011 zdecydowana większość krajów Unii Europejskiej poprawiła wynik ekonomiczny budżetu państwa w relacji do PKB, nadal kontynuowany był proces wzrostu długu publicznego jako \% PKB. W okresie tym dług publiczny zmniejszył się jedynie w Szwecji oraz Estonii.

W latach 2012-2013 większość krajów UE utrzymywała się na ścieżce redukcji deficytu ekonomicznego budżetu państwa w relacji do PKB. W tym czasie wynik budżetu państwa poprawił się w 19 państwach. W 6 spośród nich (Irlandia, Chorwacja, Łotwa, Litwa, Polska, Rumunia) jedyną determinantą poprawy wyniku ekonomicznego w relacji do PKB był spadek udziału wydatków budżetowych w PKB. Niestety, tylko w Irlandii i Chorwacji o spadku wydatków budżetu państwa jako \%

9 Gdy rośnie nominalny PKB (zwłaszcza gdy ma to miejsce w warunkach wzrostu gospodarczego), często nominalne dochody budżetowe zwiększają się w tempie większym od tempa wzrostu nominalnego PKB, co owocuje z kolei zwiększeniem dochodów budżetowych w relacji do PKB. 
PKB zdecydowało zmniejszenie nominalnych wydatków budżetowych, a więc polityka budżetowa. W pozostałych 4 krajach spadek udziału wydatków budżetowych w PKB nastąpił tylko lub niemal wyłącznie dzięki wzrostowi nominalnego PKB, a więc poprzez poprawę koniunktury gospodarczej (natomiast nominalne wydatki budżetowe zwiększały się). W kolejnych 6 krajach (Czechy, Dania, Niemcy, Hiszpania, Cypr, Wielka Brytania) istotnymi źródłami zmniejszenia deficytu ekonomicznego jako \% PKB były zarówno spadek wydatków budżetowych w relacji do PKB, jak i wzrost udziału dochodów budżetowych w PKB. Aż w 5 z tych państw (wyjątek stanowił Cypr) jedyną determinantą redukcji wydatków budżetowych w relacji do PKB był wzrost nominalnego PKB (rosły bowiem nominalne wydatki budżetowe). Natomiast w 7 krajach (Belgia, Bułgaria, Francja, Włochy, Holandia, Austria, Słowacja) wynik ekonomiczny budżetu państwa poprawił się wyłącznie dzięki wzrostowi dochodów budżetowych jako \% PKB. W 6 spośród tych krajów o wzroście udziału dochodów budżetowych w PKB zdecydował wzrost nominalnego PKB (który wywołał więcej niż proporcjonalny wzrost nominalnych dochodów budżetowych), we Włoszech zaś wzrost obciążeń podatkowych. W tych 7 krajach w latach 2012-2013 wzrosły natomiast wydatki budżetowe jako \% PKB. W każdym przypadku (z wyjątkiem Włoch) przyczyną tego była polityka budżetowa kreująca wzrost nominalnych wydatków budżetowych.

W latach 2012-2013 w 9 krajach UE zanotowano pogorszenie wyniku ekonomicznego budżetu państwa jako \% PKB. W 6 z nich (Luksemburg, Malta, Słowenia, Finlandia, Szwecja, Grecja) jedynym źródłem tego zjawiska był wzrost udziału wydatków budżetowych w PKB. Tylko w Grecji wzrost wydatków budżetowych jako $\%$ PKB był spowodowany zmniejszeniem nominalnego PKB (nominalne wydatki budżetowe zmniejszyły się). W pozostałych krajach za wzrostem wydatków budżetowych w relacji do PKB stał jedynie bądź głównie wzrost nominalnych wydatków budżetowych. W okresie 2012-2013 najwyższe w UE tempo wzrostu nominalnych wydatków budżetowych zanotowano w Słowenii. W porównaniu z 2011 r. roczne nominalne wydatki budżetowe wzrosły aż o 16,2\% (a nominalny PKB zmniejszył się o 2,4\%). W efekcie w $2013 \mathrm{r}$. Słowenia stała się krajem o największym na świecie udziale wydatków budżetowych w PKB (59,4\%). W Portugalii i na Węgrzech jedynym źródłem pogorszenia się wyniku ekonomicznego budżetu państwa w latach 2012-2013 był spadek udziału dochodów budżetowych w PKB. Przy czym w przypadku Węgier pogorszenie wyniku budżetowego w porównaniu z 2011 r. miało charakter czysto statystyczny i mówienie o pogłębieniu nierównowagi budżetowej nie jest zasadne. Jest to skutek tego, że osiągnięta w 2011 r. nadwyżka ekonomiczna budżetu państwa na poziomie 4,3\% PKB wynikała $\mathrm{z}$ wprowadzonych w tym roku na Węgrzech zmian $\mathrm{w}$ funkcjonowaniu systemu emerytalnego. W ich efekcie do dochodów budżetowych 
2011 r. zaliczono sumę składek emerytalnych zgromadzonych przez lata w prywatnych funduszach emerytalnych. Z identyczną sytuacją mamy do czynienia w Polsce w 2014 r., w którym także budżet państwa zamknie się nadwyżką ekonomiczną. W porównaniu z $2010 \mathrm{r}$. w 2013 r. zanotowano na Węgrzech znacznie niższy deficyt ekonomiczny budżetu państwa jako \% PKB (2,2\% PKB zamiast 4,3\%).

W okresie 2012-2013 nadal obserwowaliśmy wzrost długu publicznego jako \% PKB w zdecydowanej większości krajów UE. W tym czasie dług publiczny zmniejszył się jedynie w Danii, Niemczech, na Łotwie i na Węgrzech.

W latach 2008-2009 w Unii Europejskiej traktowanej jako całość deficyt ekonomiczny budżetu państwa wzrósł w porównaniu z 2007 r. z 0,9\% PKB do 6,9\% PKB. Z kolei lata 2010-2013 to okres systematycznego zmniejszania się tego deficytu do poziomu 3,3\% PKB w $2013 \mathrm{r}$. W roku 2013 podobny deficyt budżetowy jak w całej UE zanotowano w samej strefie euro (3,0\% PKB). Mimo że w ostatnich latach nierównowaga budżetowa w UE zmniejsza się, nie możemy mówić o końcu kryzysu finansów publicznych. Przez cały okres 2008-2013 rośnie bowiem dług publiczny $\mathrm{w}$ relacji do $\mathrm{PKB}$, a ponadto jest on na bardzo wysokim poziomie. Na koniec $2013 \mathrm{r}$. dług publiczny dla całej UE wyniósł $87,1 \%$, podczas gdy na koniec 2007 r. wynosił $58,8 \%$ PKB. Na koniec 2013 r. dług publiczny dla samej strefy euro kształtował się na poziomie $92,7 \% \mathrm{PKB}$.

Ponadto należy podkreślić, że w 2013 r. nadal aż w 10 krajach UE (w tym w Polsce) deficyt ekonomiczny budżetu państwa przekraczał 3,0\% PKB (a więc kryterium z Maastricht w tym zakresie). Najwyższe deficyty zanotowano w Słowenii (14,7\% PKB), Grecji (12,7\% PKB), Irlandii (7,2\% PKB), Hiszpanii (7,1\% PKB), Wielkiej Brytanii (5,8\% PKB), na Cyprze (5,4\% PKB). Na koniec 2013 r. aż w 16 krajach Unii Europejskiej dług publiczny przekraczał 60,0\% PKB (kryterium z Maastricht w tym zakresie). W 9 krajach dług publiczny przekroczył 80,0\% PKB, a już w $6-100,0 \%$ PKB. Do tej ostatniej grupy należą Grecja (175,1\% PKB), Włochy (132,6\% PKB), Portugalia (129,0\% PKB), Irlandia (123,7\% PKB), Cypr (111,7\% PKB) oraz Belgia (101,5\% PKB). Warto zauważyć, że aż w 7 krajach, które należą do państw o długu publicznym powyżej $80,0 \% \mathrm{PKB}$, nadal jest notowany wysoki deficyt ekonomiczny budżetu państwa jako \% PKB, co oznacza, że dług publiczny ciągle znacząco przyrasta (te kraje to Grecja, Portugalia, Irlandia, Cypr, Francja, Hiszpania, Wielka Brytania) ${ }^{10}$.

Poniżej zostały zaprezentowane szczegółowe dane obrazujące kształtowanie się wyniku ekonomicznego budżetu państwa i długu publicznego oraz kategorii determinujących ich zmienność w krajach Unii Europejskiej w latach 2011-2013. Materiał ten stanowi kontynuację moich opracowań statystycznych prezentujących sytuację

${ }^{10}$ Na podstawie danych Eurostatu. 
finansów publicznych krajów UE zawartych w artykułach przygotowanych w ramach badań statutowych we wcześniejszych latach.

Tabela 1. Tempo zmiany realnego PKB w krajach UE w latach 2012-2013

\begin{tabular}{|l|c|c|}
\hline \multicolumn{1}{|c|}{ Kraj } & 2012 & 2013 \\
\hline Austria & 0,9 & 0,3 \\
\hline Belgia & $-0,1$ & 0,2 \\
\hline Butgaria & 0,6 & 0,9 \\
\hline Chorwacja & $-2,2$ & $-0,9$ \\
\hline Cypr & $-2,4$ & $-5,4$ \\
\hline Czechy & $-1,0$ & $-0,9$ \\
\hline Dania & $-0,4$ & 0,4 \\
\hline Estonia & 4,5 & 2,2 \\
\hline Finlandia & $-1,0$ & $-1,4$ \\
\hline Francja & 0,0 & 0,2 \\
\hline Grecja & $-7,0$ & $-3,9$ \\
\hline Hiszpania & $-1,6$ & $-1,2$ \\
\hline Holandia & $-1,2$ & $-0,8$ \\
\hline Irlandia & 0,2 & $-0,3$ \\
\hline Litwa & 3,7 & 3,3 \\
\hline Luksemburg & $-0,2$ & 2,1 \\
\hline Łotwa & 5,2 & 4,1 \\
\hline Malta & 1,1 & 2,9 \\
\hline Niemcy & 0,7 & 0,4 \\
\hline Polska & 2,0 & 1,6 \\
\hline Portugalia & $-3,2$ & $-1,4$ \\
\hline Rumunia & 0,6 & 3,5 \\
\hline Stowacja & 1,8 & 0,9 \\
\hline Stowenia & $-2,5$ & $-1,1$ \\
\hline Szwecja & 0,9 & 1,6 \\
\hline Węgry & $-1,7$ & $-1,9$ \\
\hline Wielka Brytania & 0,3 & \\
\hline Włochy & $-2,4$ & \\
\hline & & \\
\hline & & \\
\hline & & \\
\hline
\end{tabular}

Źródło: Opracowanie własne na podstawie danych Eurostatu.

Tabela 2. Wynik ekonomiczny budżetu państwa jako \% PKB w krajach UE w latach 2011-2013

\begin{tabular}{|l|l|l|l|}
\hline \multicolumn{1}{|c|}{ Kraj } & 2011 & 2012 & 2013 \\
\hline Austria & $-2,5$ & $-2,6$ & $-1,5$ \\
\hline Belgia & $-3,8$ & $-4,1$ & $-2,6$ \\
\hline
\end{tabular}




\begin{tabular}{|c|c|c|c|}
\hline Kraj & 2011 & 2012 & 2013 \\
\hline Bułgaria & $-2,0$ & $-0,8$ & $-1,5$ \\
\hline Chorwacja & $-7,8$ & $-5,0$ & $-4,9$ \\
\hline Cypr & $-6,3$ & $-6,4$ & $-5,4$ \\
\hline Czechy & $-3,2$ & $-4,2$ & $-1,5$ \\
\hline Dania & $-1,9$ & $-3,8$ & $-0,8$ \\
\hline Estonia & 1,1 & $-0,2$ & $-0,2$ \\
\hline Finlandia & $-0,7$ & $-1,8$ & $-2,1$ \\
\hline Francja & $-5,2$ & $-4,9$ & $-4,3$ \\
\hline Grecja & $-9,6$ & $-8,9$ & $-12,7$ \\
\hline Hiszpania & $-9,6$ & $-10,6$ & $-7,1$ \\
\hline Holandia & $-4,3$ & $-4,1$ & $-2,5$ \\
\hline Irlandia & $-13,1$ & $-8,2$ & $-7,2$ \\
\hline Litwa & $-5,5$ & $-3,2$ & $-2,2$ \\
\hline Luksemburg & 0,2 & 0,0 & 0,1 \\
\hline Łotwa & $-3,5$ & $-1,3$ & $-1,0$ \\
\hline Malta & $-2,7$ & $-3,3$ & $-2,8$ \\
\hline Niemcy & $-0,8$ & 0,1 & 0,0 \\
\hline Polska & $-5,1$ & $-3,9$ & $-4,3$ \\
\hline Portugalia & $-4,3$ & $-6,4$ & $-4,9$ \\
\hline Rumunia & $-5,5$ & $-3,0$ & $-2,3$ \\
\hline Słowacja & $-4,8$ & $-4,5$ & $-2,8$ \\
\hline Stowenia & $-6,4$ & $-4,0$ & $-14,7$ \\
\hline Szwecja & 0,2 & $-0,6$ & $-1,1$ \\
\hline Węgry & 4,3 & $-2,1$ & $-2,2$ \\
\hline Wielka Brytania & $-7,6$ & $-6,1$ & $-5,8$ \\
\hline Włochy & $-3,7$ & $-3,0$ & $-3,0$ \\
\hline
\end{tabular}

Źródło: Opracowanie własne na podstawie danych Eurostatu.

Tabela 3. Dochody budżetowe jako \% PKB w krajach UE w latach 2011-2013

\begin{tabular}{|l|c|c|c|}
\hline \multicolumn{1}{|c|}{ Kraj } & 2011 & 2012 & 2013 \\
\hline Austria & 48,3 & 49,1 & 49,7 \\
\hline Belgia & 49,6 & 51,0 & 51,8 \\
\hline Butgaria & 33,6 & 35,0 & 37,2 \\
\hline Chorwacja & 40,3 & 41,0 & 41,2 \\
\hline Cypr & 39,9 & 39,4 & 40,3 \\
\hline Czechy & 40,0 & 40,3 & 40,9 \\
\hline Dania & 55,7 & 55,5 & 56,3 \\
\hline Estonia & 38,7 & 39,2 & 38,1 \\
\hline Finlandia & 54,1 & 54,5 & 56,0 \\
\hline Francja & 50,7 & 51,8 & 52,8 \\
\hline
\end{tabular}




\begin{tabular}{|l|c|c|c|}
\hline \multicolumn{1}{|c|}{ Kraj } & 2011 & 2012 & 2013 \\
\hline Grecja & 42,2 & 44,4 & 45,8 \\
\hline Hiszpania & 36,2 & 37,2 & 37,8 \\
\hline Holandia & 45,6 & 46,4 & 47,3 \\
\hline Irlandia & 34,0 & 34,5 & 35,9 \\
\hline Litwa & 33,2 & 32,7 & 32,2 \\
\hline Luksemburg & 42,7 & 44,0 & 43,6 \\
\hline Łotwa & 34,9 & 35,1 & 35,1 \\
\hline Malta & 38,6 & 39,8 & 40,9 \\
\hline Niemcy & 44,3 & 44,8 & 44,7 \\
\hline Polska & 38,4 & 38,3 & 37,5 \\
\hline Portugalia & 45,0 & 40,9 & 43,7 \\
\hline Rumunia & 33,9 & 33,7 & 32,7 \\
\hline Słowacja & 34,1 & 33,7 & 35,9 \\
\hline Słowenia & 43,5 & 44,4 & 44,7 \\
\hline Szwecja & 51,5 & 51,2 & 51,6 \\
\hline Węgry & 54,3 & 46,6 & 47,7 \\
\hline Wielka Brytania & 40,3 & 42,0 & 41,4 \\
\hline Włochy & 46,1 & 47,7 & 47,7 \\
\hline
\end{tabular}

Źródło: Opracowanie własne na podstawie danych Eurostatu.

Tabela 4. Wydatki budżetowe jako \% PKB w krajach UE w latach 2011-2013

\begin{tabular}{|l|c|c|c|}
\hline \multicolumn{1}{|c|}{ Kraj } & 2011 & 2012 & 2013 \\
\hline Austria & 50,8 & 51,6 & 51,3 \\
\hline Belgia & 53,6 & 55,1 & 54,5 \\
\hline Butgaria & 35,6 & 35,8 & 38,7 \\
\hline Chorwacja & 48,1 & 46,0 & 46,1 \\
\hline Cypr & 46,3 & 45,8 & 45,8 \\
\hline Czechy & 43,2 & 44,5 & 42,3 \\
\hline Dania & 57,7 & 59,4 & 57,2 \\
\hline Estonia & 37,6 & 39,5 & 38,3 \\
\hline Finlandia & 55,1 & 56,7 & 58,5 \\
\hline Francja & 55,9 & 56,7 & 57,1 \\
\hline Grecja & 51,9 & 53,4 & 58,5 \\
\hline Hiszpania & 45,7 & 47,8 & 44,8 \\
\hline Holandia & 49,9 & 50,4 & 49,8 \\
\hline Irlandia & 47,1 & 42,6 & 42,9 \\
\hline Litwa & 38,7 & 36,1 & 36,4 \\
\hline Luksemburg & 42,6 & 43,9 & 43,5 \\
\hline Łotwa & 38,4 & 36,5 & 36,1 \\
\hline
\end{tabular}




\begin{tabular}{|l|l|l|l|}
\hline \multicolumn{1}{|c|}{ Kraj } & 2011 & 2012 & 2013 \\
\hline Malta & 41,4 & 43,1 & 43,7 \\
\hline Niemcy & 45,2 & 44,7 & 44,7 \\
\hline Polska & 43,4 & 42,2 & 41,9 \\
\hline Portugalia & 49,3 & 47,4 & 48,7 \\
\hline Rumunia & 39,4 & 36,7 & 35,0 \\
\hline Słowacja & 38,9 & 38,2 & 38,7 \\
\hline Słowenia & 49,9 & 48,4 & 59,4 \\
\hline Szwecja & 51,5 & 52,0 & 52,8 \\
\hline Wegry & 50,0 & 48,7 & 50,0 \\
\hline Wielka Brytania & 47,9 & 48,1 & 47,1 \\
\hline Włochy & 49,7 & 50,6 & 50,6 \\
\hline
\end{tabular}

Źródło: Opracowanie własne na podstawie danych Eurostatu.

Tabela 5. Tempo zmiany rocznego nominalnego $\mathrm{PKB}$, rocznych nominalnych dochodów budżetowych oraz rocznych nominalnych wydatków budżetowych w krajach UE w latach 2012-2013

\begin{tabular}{|l|c|c|c|}
\hline \multicolumn{1}{|c|}{ Kraj } & 2011 & 2012 & 2013 \\
\hline Austria & 4,7 & 7,7 & 5,5 \\
\hline Belgia & 3,9 & 8,3 & 5,5 \\
\hline Butgaria & 3,7 & 14,8 & 12,8 \\
\hline Chorwacja & $-0,1$ & 1,6 & $-4,7$ \\
\hline Cypr & $-7,7$ & $-6,8$ & $-8,7$ \\
\hline Czechy & 1,6 & 3,9 & $-0,5$ \\
\hline Dania & 3,7 & 4,7 & 2,7 \\
\hline Estonia & 13,7 & 11,9 & 15,8 \\
\hline Finlandia & 2,5 & 6,1 & 8,8 \\
\hline Francja & 2,9 & 7,2 & 5,1 \\
\hline Grecja & $-12,7$ & $-5,3$ & $-1,6$ \\
\hline Hiszpania & $-2,2$ & 2,1 & $-4,2$ \\
\hline Holandia & 0,6 & 4,4 & 0,4 \\
\hline Irlandia & 0,9 & 6,5 & $-8,1$ \\
\hline Litwa & 11,8 & 8,7 & $-0,4$ \\
\hline Luksemburg & 9,0 & 11,3 & 11,3 \\
\hline Łotwa & 14,8 & 15,4 & 7,9 \\
\hline Malta & 7,3 & 14,3 & 14,1 \\
\hline Niemcy & 4,9 & 5,8 & 3,7 \\
\hline Polska & 7,0 & 4,6 & 3,3 \\
\hline Portugalia & $-3,2$ & $-6,1$ & $-4,4$ \\
\hline Rumunia & 12,8 & 8,8 & 0,2 \\
\hline
\end{tabular}




\begin{tabular}{|l|c|c|c|}
\hline \multicolumn{1}{|c|}{ Kraj } & 2011 & 2012 & 2013 \\
\hline Stowacja & 4,6 & 10,1 & 4,0 \\
\hline Stowenia & $-2,4$ & 2,7 & 16,2 \\
\hline Szwecja & 4,4 & 4,4 & 7,3 \\
\hline Węgry & 5,4 & $-7,6$ & 5,4 \\
\hline Wielka Brytania & 5,0 & 7,6 & 3,2 \\
\hline Włochy & $-1,3$ & 2,2 & 0,5 \\
\hline
\end{tabular}

Źródło: Opracowanie własne na podstawie danych Eurostatu.

Tabela 6. Dług publiczny w relacji do PKB (na koniec roku) w krajach UE w latach 2011-2013

\begin{tabular}{|c|c|c|c|}
\hline Kraj & 2011 & 2012 & 2013 \\
\hline Austria & 73,1 & 74,4 & 74,5 \\
\hline Belgia & 99,2 & 101,1 & 101,5 \\
\hline Bułgaria & 16,3 & 18,4 & 18,9 \\
\hline Chorwacja & 52,0 & 55,9 & 67,1 \\
\hline Cypr & 71,5 & 86,6 & 111,7 \\
\hline Czechy & 41,4 & 46,2 & 46,0 \\
\hline Dania & 46,4 & 45,4 & 44,5 \\
\hline Estonia & 6,1 & 9,8 & 10,0 \\
\hline Finlandia & 49,3 & 53,6 & 57,0 \\
\hline Francja & 86,2 & 90,6 & 93,5 \\
\hline Grecja & 170,3 & 157,2 & 175,1 \\
\hline Hiszpania & 70,5 & 86,0 & 93,9 \\
\hline Holandia & 65,7 & 71,3 & 73,5 \\
\hline Irlandia & 104,1 & 117,4 & 123,7 \\
\hline Litwa & 38,3 & 40,5 & 39,4 \\
\hline Luksemburg & 18,7 & 21,7 & 23,1 \\
\hline Łotwa & 42,0 & 40,8 & 38,1 \\
\hline Malta & 68,8 & 70,8 & 73,0 \\
\hline Niemcy & 80,0 & 81,0 & 78,4 \\
\hline Polska & 56,2 & 55,6 & 57,0 \\
\hline Portugalia & 108,2 & 124,1 & 129,0 \\
\hline Rumunia & 34,7 & 38,0 & 38,4 \\
\hline Słowacja & 43,6 & 52,7 & 55,4 \\
\hline Stowenia & 47,1 & 54,4 & 71,7 \\
\hline Szwecja & 38,6 & 38,3 & 40,6 \\
\hline Węgry & 82,1 & 79,8 & 79,2 \\
\hline Wielka Brytania & 84,3 & 89,1 & 90,6 \\
\hline Włochy & 120,7 & 127,0 & 132,6 \\
\hline
\end{tabular}

Źródło: Opracowanie własne na podstawie danych Eurostatu. 
W tym miejscu warto zwrócić uwagę na sytuację finansów publicznych w ostatnich latach 2 krajów, które nie są członkami Unii Europejskiej, ale należą do ścisłej czołówki światowej w zakresie PKB per capita według parytetu siły nabywczej. Chodzi mianowicie o Norwegię i Szwajcarię.

W Norwegii w latach 2008-2013 utrzymywała się bardzo wysoka nadwyżka ekonomiczna budżetu państwa jako \% PKB. Dzięki temu nastąpiło znaczące zmniejszenie długu publicznego w relacji do PKB. Na koniec 2007 r. wynosił on 51,5\% PKB, a na koniec 2013 r. zaledwie $29,5 \%$ PKB.

W Szwajcarii po $2007 \mathrm{r}$. budżet państwa zamykał się bardzo niskim deficytem ekonomicznym, a dług publiczny kształtował się w granicach 45,0-50,0\% PKB.

Zatem Norwegia i Szwajcaria na koniec 2013 r. odznaczały się znacznie niższym poziomem długu publicznego w porównaniu ze średnią krajów UE w tym zakresie.

Tabela 7. Wynik ekonomiczny budżetu państwa jako \% PKB oraz dług publiczny jako \% PKB w Norwegii w latach 2008-2013

\begin{tabular}{|l|c|c|c|c|c|c|}
\hline & 2008 & 2009 & 2010 & 2011 & 2012 & 2013 \\
\hline Wynik ekonomiczny budżetu państwa jako \% PKB & 10,8 & 10,5 & 11,1 & 13,6 & 13,9 & 11,1 \\
\hline Dług publiczny jako \% PKB (na koniec roku) & 48,2 & 42,8 & 42,5 & 27,8 & 29,1 & 29,5 \\
\hline
\end{tabular}

Źródło: Opracowanie własne na podstawie danych Eurostatu.

Tabela 8. Wynik ekonomiczny budżetu państwa jako \% PKB oraz dług publiczny jako \% PKB w Szwajcarii w latach 2008-2012

\begin{tabular}{|l|c|c|c|c|c|c|}
\hline & 2008 & 2009 & 2010 & 2011 & 2012 & 2013 \\
\hline Wynik ekonomiczny budżetu państwa jako \% PKB & $-2,0$ & $-0,8$ & $-0,3$ & $-0,7$ & $-0,2$ & - \\
\hline Dług publiczny jako \% PKB (na koniec roku) & 50,4 & 49,7 & 48,5 & 49,1 & 46,7 & 45,6 \\
\hline
\end{tabular}

Źródło: Opracowanie własne na podstawie danych Eurostatu.

\section{Zmienność deficytu ekonomicznego budżetu państwa i długu publicznego w wybranych gospodarkach pozaeuropejskich po 2007 roku}

\subsection{Sytuacja finansów publicznych w krajach Ameryki Północnej}

W USA w 2007 r. budżet państwa zamknął się deficytem ekonomicznym w wysokości 4,0\% PKB. W latach 2008-2009 deficyt ten zwiększył się do 14,7\% PKB. Równie istotnymi źródłami wzrostu deficytu budżetowego w tym okresie były spadek 
dochodów budżetowych jako \% PKB i wzrost wydatków budżetowych w relacji do PKB. Za tymi dwoma zjawiskami w głównej mierze stała polityka budżetowa, a nie spadek nominalnego PKB. Wzrost udziału wydatków budżetowych w PKB był bowiem przede wszystkim spowodowany wzrostem nominalnych wydatków budżetowych, a spadek dochodów budżetowych w relacji do PKB to efekt głównie reform podatkowych zmniejszających obciążenia podatkowe.

W latach 2010-2013 obserwowaliśmy systematyczną redukcję deficytu ekonomicznego budżetu państwa jako \% PKB aż do poziomu 7,3\% PKB w 2013 r. Do zmniejszenia deficytu budżetowego w podobnym stopniu przyczyniły się wzrost dochodów budżetowych jako \% PKB i zmniejszenie udziału wydatków budżetowych w PKB. Spadek wydatków budżetowych w relacji do PKB to efekt wzrostu nominalnego PKB, aczkolwiek należy podkreślić to, że w latach 2011-2013 udało się praktycznie zapobiec wzrostowi nominalnych wydatków budżetowych.

Lata 2008-2013 to okres drastycznego wzrostu długu publicznego w relacji do PKB. Na koniec 2013 r. osiągnął on 104,5\% PKB (podczas gdy na koniec 2007 r. kształtował się na poziomie 64,0\% PKB).

Tabela 9. Tempo zmiany nominalnego PKB oraz tempo zmiany realnego PKB w USA w latach 2008-2013

\begin{tabular}{|l|r|r|r|r|r|r|}
\hline & 2008 & 2009 & 2010 & 2011 & 2012 & 2013 \\
\hline Tempo zmiany nominalnego PKB & 1,7 & $-2,1$ & 3,7 & 3,8 & 4,6 & 3,4 \\
\hline Tempo zmiany realnego PKB & $-0,3$ & $-2,8$ & 2,5 & 1,8 & 2,8 & 1,9 \\
\hline
\end{tabular}

Źródło: Opracowanie własne na podstawie danych Banku Światowego.

Tabela 10. Wynik ekonomiczny budżetu państwa jako \% PKB oraz dług publiczny jako \% PKB w USA w latach 2008-2013

\begin{tabular}{|l|r|r|r|r|r|r|}
\hline & 2008 & 2009 & 2010 & 2011 & 2012 & 2013 \\
\hline $\begin{array}{l}\text { Wynik ekonomiczny budżetu państwa jako } \\
\text { \% PKB }\end{array}$ & $-7,8$ & $-14,7$ & $-12,5$ & $-11,0$ & $-9,7$ & $-7,3$ \\
\hline Dług publiczny jako \% PKB (na koniec roku) & 72,8 & 86,1 & 94,8 & 99,0 & 102,4 & 104,5 \\
\hline
\end{tabular}

Źródło: Opracowanie własne na podstawie danych Banku Światowego.

Tabela 11. Dochody budżetowe jako \% PKB oraz wydatki budżetowe jako \% PKB w USA w latach 2008-2013

\begin{tabular}{|l|r|r|r|r|r|r|}
\hline & 2008 & 2009 & 2010 & 2011 & 2012 & 2013 \\
\hline Dochody budżetowe jako \% PKB & 25,6 & 22,8 & 25,4 & 25,7 & 25,7 & 26,9 \\
\hline Wydatki budżetowe jako \% PKB & 33,5 & 37,5 & 38,0 & 36,8 & 35,3 & 34,3 \\
\hline
\end{tabular}

Źródło: Opracowanie własne na podstawie danych Banku Światowego. 
Tabela 12. Tempo zmiany nominalnych dochodów budżetowych oraz nominalnych wydatków budżetowych w USA w latach 2008-2013

\begin{tabular}{|l|c|c|c|c|c|c|}
\hline & 2008 & 2009 & 2010 & 2011 & 2012 & 2013 \\
\hline $\begin{array}{l}\text { Tempo zmiany nominalnych dochodów } \\
\text { budżetowych }\end{array}$ & $-8,0$ & $-13,0$ & 15,8 & 5,1 & 4,3 & 8,4 \\
\hline $\begin{array}{l}\text { Tempo zmiany nominalnych wydatków } \\
\text { budżetowych }\end{array}$ & 5,1 & 9,8 & 5,0 & 0,6 & 0,5 & 0,2 \\
\hline
\end{tabular}

Źródło: Opracowanie własne na podstawie danych Banku Światowego.

W Kostaryce w 2007 r. w budżecie państwa zanotowano nadwyżkę ekonomiczną na poziomie 1,9\% PKB. W latach 2008-2010 wynik ekonomiczny budżetu państwa jako \% PKB pogorszył się o blisko 7 pkt. proc. (w 2010 r. deficyt ekonomiczny na poziomie 5,0\% PKB). Za ten wzrost deficytu ekonomicznego budżetu państwa niemal w całości był odpowiedzialny wzrost udziału wydatków budżetowych w PKB, którego z kolei jedynym źródłem była polityka budżetowa kreująca gigantyczny wzrost nominalnych wydatków budżetowych (w latach 2008-2010 wzrósł bowiem nie tylko nominalny, ale także realny PKB). Lata 2011-2012 przyniosły redukcję deficytu ekonomicznego budżetu państwa do poziomu 3,7\% PKB, której wyłączną determinantą był wzrost wydatków budżetowych jako \% PKB. Do wzrostu wydatków budżetowych w relacji do PKB przyczynił się wyłącznie wzrost nominalnego PKB, nadal bowiem obserwowaliśmy wysokie tempo wzrostu nominalnych wydatków budżetowych.

W latach 2008-2013 dług publiczny Kostaryki wzrósł z 46,6\% PKB (na koniec 2007 r.) do 55,1\% PKB.

Tabela 13. Tempo zmiany nominalnego PKB oraz realnego PKB w Kostaryce w latach 2008-2012

\begin{tabular}{|l|c|c|c|c|c|}
\hline & 2008 & 2009 & 2010 & 2011 & 2012 \\
\hline Tempo zmiany nominalnego PKB & 15,5 & 5,0 & 15,5 & 8,5 & 9,8 \\
\hline Tempo zmiany realnego PKB & 2,7 & $-1,0$ & 4,7 & 4,2 & 5,0 \\
\hline
\end{tabular}

Źródło: Opracowanie własne na podstawie danych Banku Światowego.

Tabela 14. Wynik ekonomiczny budżetu państwa jako \% PKB w Kostaryce w latach 2008-2012

\begin{tabular}{|l|c|c|c|c|c|}
\hline & 2008 & 2009 & 2010 & 2011 & 2012 \\
\hline $\begin{array}{l}\text { Wynik ekonomiczny budżetu } \\
\text { państwa jako \% PKB }\end{array}$ & 0,4 & $-3,2$ & $-5,0$ & $-3,7$ & $-3,7$ \\
\hline
\end{tabular}

Źródło: Opracowanie własne na podstawie danych Banku Światowego. 
Tabela 15. Dochody budżetowe jako \% PKB oraz wydatki budżetowe jako \% PKB w Kostaryce w latach 2008-2012

\begin{tabular}{|l|c|c|c|c|c|}
\hline & 2008 & 2009 & 2010 & 2011 & 2012 \\
\hline Dochody budżetowe jako \% PKB & 23,6 & 22,6 & 22,4 & 22,5 & 22,4 \\
\hline Wydatki budżetowe jako \% PKB & 23,2 & 25,8 & 27,4 & 26,2 & 26,1 \\
\hline
\end{tabular}

Źródło: Opracowanie własne na podstawie danych Banku Światowego.

Tabela 16. Tempo zmiany nominalnych dochodów budżetowych oraz nominalnych wydatków budżetowych w Kostaryce w latach 2008-2012

\begin{tabular}{|l|c|c|c|c|c|}
\hline & 2008 & 2009 & 2010 & 2011 & 2012 \\
\hline $\begin{array}{l}\text { Tempo zmiany nominalnych dochodów } \\
\text { budżetowych }\end{array}$ & 16,1 & 2,9 & 11,8 & 10,1 & 8,4 \\
\hline $\begin{array}{l}\text { Tempo zmiany nominalnych wydatków } \\
\text { budżetowych }\end{array}$ & 24,4 & 19,3 & 19,9 & 3,9 & 9,6 \\
\hline
\end{tabular}

Źródło: Opracowanie własne na podstawie danych Banku Światowego.

W Kanadzie w 2007 r. budżet państwa zamknął się nadwyżką ekonomiczną w wysokości 0,9\% PKB. W latach 2008-2009 deficyt ekonomiczny wzrósł do poziomu 8,9\% PKB. Z kolei w latach 2010-2012 zredukowano deficyt budżetowy do poziomu 2,4\% PKB. W roku 2013 w budżecie państwa odnotowano deficyt ekonomiczny na poziomie 2,9\% PKB. Na koniec 2013 r. dług publiczny wyniósł 86,0\% PKB.

W innej ważnej gospodarce północnoamerykańskiej, a mianowicie w Meksyku dług publiczny na koniec 2013 r. stanowił 37,7\% PKB, a w 2013 r. budżet zamknął się deficytem ekonomicznym w wysokości 2,5\% PKB.

Na koniec 2013 r. w dwóch największych gospodarkach Ameryki Północnej, czyli USA i Kanadzie dług publiczny był zbliżony do średniego długu publicznego w krajach Unii Europejskiej.

\subsection{Sytuacja finansów publicznych w krajach Ameryki Południowej}

W Brazylii w 2007 r. deficyt ekonomiczny budżetu państwa wyniósł 1,9\% PKB. W okresie 2008-2009 nastąpił nieznaczny wzrost tego deficytu do poziomu 3,1\% PKB. W latach 2010-2012 budżet zamykał się deficytem ekonomicznym na poziomie poniżej 2\% PKB. W $2013 \mathrm{r}$. z kolei deficyt ten wzrósł do 2,8\% PKB. W latach 2008-2013 dług publiczny był stabilny i na koniec 2013 r. wyniósł 58,8\% PKB. 
Tabela 17. Wynik ekonomiczny budżetu państwa jako \% PKB oraz dług publiczny jako \% PKB w Brazylii w latach 2008-2013

\begin{tabular}{|l|c|c|c|c|c|c|}
\hline & 2008 & 2009 & 2010 & 2011 & 2012 & 2013 \\
\hline Wynik ekonomiczny budżetu państwa jako \% PKB & $-1,2$ & $-3,1$ & $-1,3$ & $-1,8$ & $-1,7$ & $-2,8$ \\
\hline Dług publiczny jako \% PKB (na koniec roku) & 60,0 & 57,4 & 60,9 & 53,4 & 54,2 & 58,8 \\
\hline
\end{tabular}

Źródło: Opracowanie własne na podstawie danych Banku Światowego.

Tabela 18. Dochody budżetowe jako \% PKB oraz wydatki budżetowe jako \% PKB w Brazylii w latach 2008-2013

\begin{tabular}{|l|r|r|r|r|r|r|}
\hline & 2008 & 2009 & 2010 & 2011 & 2012 & 2013 \\
\hline Dochody budżetowe jako \% PKB & 19,0 & 20,6 & 19,4 & 16,3 & 21,5 & 24,7 \\
\hline Wydatki budżetowe jako \% PKB & 20,2 & 23,7 & 20,7 & 18,0 & 23,3 & 27,5 \\
\hline
\end{tabular}

Źródło: Opracowanie własne na podstawie danych Banku Światowego.

Tabela 19. Tempo zmiany nominalnych dochodów budżetowych oraz nominalnych wydatków budżetowych w Brazylii w latach 2010-2013

\begin{tabular}{|l|r|r|r|r|}
\hline & 2010 & 2011 & 2012 & 2013 \\
\hline Tempo zmiany nominalnych dochodów budżetowych & 24,4 & 7,6 & 8,5 & 14,2 \\
\hline Tempo zmiany nominalnych wydatków budżetowych & 15,4 & 11,7 & 5,8 & 17,7 \\
\hline
\end{tabular}

Źródło: Opracowanie własne na podstawie danych Banku Światowego.

W Argentynie w latach 2007-2008 budżet państwa zamykał się nadwyżką ekonomiczną. Po 2008 r. tylko w roku 2013 deficyt ekonomiczny budżetu państwa przekroczył 3,0\% PKB. W okresie 2008-2013 dług publiczny jako \% PKB utrzymywał się na relatywnie niskim poziomie i na koniec 2013 r. wyniósł 45,8\% PKB (na koniec 2008 r. 58,5\% PKB).

Tabela 20. Tempo zmiany nominalnego PKB oraz realnego PKB w Argentynie w latach 2008-2013

\begin{tabular}{|l|c|c|c|c|c|c|}
\hline & 2008 & 2009 & 2010 & 2011 & 2012 & 2013 \\
\hline Tempo zmiany nominalnego PKB & 27,1 & 10,9 & 25,9 & 27,7 & 17,5 & 22,0 \\
\hline Tempo zmiany realnego PKB & 16,8 & 2,2 & 18,4 & 15,5 & 7,0 & 10,9 \\
\hline
\end{tabular}

Źródło: Opracowanie własne na podstawie danych Banku Światowego. 
Tabela 21. Wynik ekonomiczny budżetu państwa jako \% PKB oraz dług publiczny jako \% PKB w Argentynie w latach 2008-2013

\begin{tabular}{|l|c|c|c|c|c|c|}
\hline & 2008 & 2009 & 2010 & 2011 & 2012 & 2013 \\
\hline Wynik ekonomiczny budżetu państwa jako \% PKB & 0,8 & $-1,2$ & $-0,5$ & $-2,6$ & $-2,2$ & $-3,2$ \\
\hline Dług publiczny jako \% PKB (na koniec roku) & 47,4 & 44,1 & 41,2 & 33,9 & 32,5 & 45,8 \\
\hline
\end{tabular}

Źródło: Opracowanie własne na podstawie danych Banku Światowego.

Tabela 22. Dochody budżetowe jako \% PKB oraz wydatki budżetowe jako \% PKB w Argentynie w latach 2008-2013

\begin{tabular}{|l|c|c|c|c|c|c|}
\hline & 2008 & 2009 & 2010 & 2011 & 2012 & 2013 \\
\hline Dochody budżetowe jako \% PKB & 21,6 & 23,2 & 24,8 & 24,4 & 26,2 & 27,8 \\
\hline Wydatki budżetowe jako \% PKB & 20,8 & 24,4 & 25,3 & 27,0 & 28,3 & 29,6 \\
\hline
\end{tabular}

Źródło: Opracowanie własne na podstawie danych Banku Światowego.

Tabela 23. Tempo zmiany nominalnych dochodów budżetowych oraz nominalnych wydatków budżetowych w Argentynie w latach 2008-2013

\begin{tabular}{|l|c|c|c|c|c|c|}
\hline & 2008 & 2009 & 2010 & 2011 & 2012 & 2013 \\
\hline Tempo zmiany nominalnych dochodów budżetowych & 35,2 & 19,2 & 34,7 & 25,8 & 25,7 & 29,6 \\
\hline Tempo zmiany nominalnych wydatków budżetowych & 36,2 & 30,1 & 30,8 & 36,2 & 23,2 & 27,3 \\
\hline
\end{tabular}

Źródło: Opracowanie własne na podstawie danych Banku Światowego.

W Kolumbii w 2009 r. budżet państwa zamknął się deficytem ekonomicznym w wysokości 7,0\% PKB. W latach 2010-2012 gospodarka Kolumbii znajdowała się na ścieżce poprawy wyniku ekonomicznego budżetu państwa w relacji do PKB. W efekcie w 2012 r. zanotowano w budżecie nadwyżkę ekonomiczną na poziomie 2,8\% PKB. Na konie 2012 r. dług publiczny Kolumbii wyniósł 65,3\% PKB.

W latach 2009-2013 znaczny wzrost długu publicznego zanotowano w Wenezueli: z 26,3\% PKB na koniec 2008 r. do 56,4\% na koniec 2013 r.

W Peru w 2009r. w budżecie państwa zanotowano deficyt w wysokości 1,1\% PKB. W latach 2010-2012 sektor finansów publicznych generował nadwyżkę ekonomiczną (w 2012 r. 2,0\% PKB). Na koniec 2013 r. dług publiczny wyniósł zaledwie 18,3\% PKB (na koniec 2007 r. 30,4\% PKB).

W Chile w $2009 \mathrm{r}$. zanotowano deficyt ekonomiczny budżetu państwa w wysokości 4,2\% PKB. W roku 2010 deficyt ten zredukowano do 0,4\% PKB, w latach 2011-2012 budżet zamykał się nadwyżką ekonomiczną (w 2012 r. na poziomie $0,5 \% \mathrm{PKB}$ ). Na koniec 2013 r. dług publiczny wynosił 12,3\% PKB (na koniec 2007 r. 3,9\% PKB).

Z kolei w Ekwadorze w latach 2009-2011 notowano bardzo wysokie deficyty ekonomiczne budżetu państwa w relacji do $\mathrm{PKB}$ (odpowiednio 6,6\% PKB, 7,7\% PKB, 
10,1\% PKB). Jednak na koniec 2013 r. dług publiczny wynosił zaledwie 18,8\% PKB (na koniec 2007 r. 26,7\% PKB).

Zatem przeciętny poziom długu publicznego jako \% PKB jest w krajach Ameryki Południowej znacznie niższy w porównaniu z krajami Unii Europejskiej.

\subsection{Sytuacja finansów publicznych w Australii i Nowej Zelandii}

W Australii w 2008 r. budżet państwa zamknął się nadwyżką ekonomiczną w wysokości 1,9\% PKB. Lata 2009-2010 to okres pogarszania się wyniku ekonomicznego budżetu państwa. W roku 2010 zanotowano deficyt ekonomiczny na poziomie 4,1\% PKB. Pogorszenie wyniku ekonomicznego budżetu państwa było w tym okresie determinowane przede wszystkim przez zmniejszenie udziału dochodów budżetowych w PKB. Lata 2011-2013 to czas znacznej redukcji deficytu ekonomicznego budżetu państwa, do poziomu 1,6\% PKB w 2013 r. Istotnymi determinantami zmniejszenia deficytu budżetowego były zarówno wzrost dochodów budżetowych jako \% PKB, jak i spadek wydatków budżetowych w relacji do PKB. Spadek wydatków budżetowych jako \% PKB był spowodowany wyłącznie wzrostem nominalnego PKB, ponieważ nominalne wydatki budżetowe w tym okresie nadal znacząco wzrastały. Na koniec 2013 r. dług publiczny wyniósł 32,6\% PKB (na konie 2007 r. 9,7\% PKB).

Tabela 24. Tempo zmiany nominalnego PKB oraz tempo zmiany realnego PKB w Australii w latach 2008-2013

\begin{tabular}{|l|c|c|c|c|c|c|}
\hline & 2008 & 2009 & 2010 & 2011 & 2012 & 2013 \\
\hline Tempo zmiany nominalnego PKB & 3,8 & 1,4 & 2,3 & 8,0 & 6,2 & 2,8 \\
\hline Tempo zmiany realnego PKB & 2,4 & 1,5 & 2,6 & 2,4 & 3,7 & 2,5 \\
\hline
\end{tabular}

Źródło: Opracowanie własne na podstawie danych Banku Światowego.

Tabela 25. Wynik ekonomiczny budżetu państwa jako \% PKB oraz dług publiczny jako \% PKB w Australii w latach 2008-2013

\begin{tabular}{|l|c|c|c|c|c|c|}
\hline & 2008 & 2009 & 2010 & 2011 & 2012 & 2013 \\
\hline Wynik ekonomiczny budżetu państwa jako \% PKB & 1,9 & $-2,5$ & $-4,1$ & $-3,7$ & $-3,0$ & $-1,6$ \\
\hline Dług publiczny jako \% PKB (na koniec roku) & - & 24,0 & 29,3 & 30,6 & 40,5 & 32,6 \\
\hline
\end{tabular}

Źródło: Opracowanie własne na podstawie danych Banku Światowego. 
Tabela 26. Dochody budżetowe jako \% PKB oraz wydatki budżetowe jako \% PKB w Australii w latach 2008-2013

\begin{tabular}{|l|c|c|c|c|c|c|}
\hline & 2008 & 2009 & 2010 & 2011 & 2012 & 2013 \\
\hline Dochody budżetowe jako \% PKB & 26,9 & 24,9 & 22,5 & 22,3 & 23,0 & 23,8 \\
\hline Wydatki budżetowe jako \% PKB & 24,8 & 27,0 & 26,1 & 25,6 & 25,7 & 25,3 \\
\hline
\end{tabular}

Źródło: Opracowanie własne na podstawie danych Banku Światowego.

Tabela 27. Tempo zmiany nominalnych dochodów budżetowych oraz nominalnych wydatków budżetowych w Australii w latach 2008-2013

\begin{tabular}{|l|c|c|c|c|c|c|}
\hline & 2008 & 2009 & 2010 & 2011 & 2012 & 2013 \\
\hline Tempo zmiany nominalnych dochodów budżetowych & - & $-1,6$ & $-2,0$ & 3,8 & 11,3 & 6,5 \\
\hline Tempo zmiany nominalnych wydatków budżetowych & - & 15,9 & 4,5 & 5,0 & 6,1 & 1,3 \\
\hline
\end{tabular}

Źródło: Opracowanie własne na podstawie danych Banku Światowego.

W Nowej Zelandii w 2009 r. budżet państwa zamknął się nadwyżką ekonomiczną w wysokości 1,1\% PKB. Lata 2010-2011 przyniosły drastyczne pogorszenie wyniku ekonomicznego budżetu państwa. W roku 2011 zanotowano deficyt na poziomie 7,9\% PKB. Jednak już w 2012 r. zredukowano deficyt ekonomiczny budżetu państwa do poziomu $0,5 \%$ PKB. W latach 2008-2013 nastąpił wzrost długu publicznego z 17,3\% PKB na koniec 2007 r. do 38,1\% PKB na koniec 2013 r.

Dług publiczny Australii i Nowej Zelandii jest jednak znacznie niższy od średniego długu publicznego krajów Unii Europejskiej.

\subsection{Sytuacja finansów publicznych w krajach Afryki}

W Republice Południowej Afryki w 2008 r. deficyt ekonomiczny budżetu państwa jako \% PKB wyniósł zaledwie 0,6\%. Niestety, w latach 2009-2010 deficyt ten zwiększył się do 7,7\% PKB. Wzrost deficytu ekonomicznego budżetu państwa był determinowany wyłącznie przez wzrost udziału wydatków budżetowych w PKB (w okresie tym bowiem zwiększyły się dochody budżetowe w relacji do PKB). Z kolei wzrost wydatków budżetowych był spowodowany wzrostem nominalnych wydatków budżetowych (bowiem w analizowanym okresie mieliśmy do czynienia ze wzrostem nominalnego $\mathrm{PKB})$.

W latach 2011-2013 udało się zmniejszyć deficyt ekonomiczny budżetu państwa do poziomu 5,2\% PKB. I tym razem jedynym źródłem redukcji deficytu budżetowego był spadek wydatków budżetowych w relacji do PKB. Dokonał się on, mimo że polityka budżetowa nadal kreowała wysokie tempo wzrostu nominalnych wydatków budżetowych. Było ono jednak niższe od tempa wzrostu nominalnego PKB. 
Dług publiczny na koniec 2013 r. wyniósł 42,5\% PKB, podczas gdy na koniec 2008 r. kształtował się na poziomie 31,6\% PKB.

Tabela 28. Tempo zmiany nominalnego PKB oraz realnego PKB w RPA w latach 2008-2013

\begin{tabular}{|l|r|r|r|r|r|r|}
\hline & 2008 & 2009 & 2010 & 2011 & 2012 & 2013 \\
\hline Tempo zmiany nominalnego PKB & 16,5 & 12,6 & 6,3 & 8,9 & 12,3 & 7,1 \\
\hline Tempo zmiany realnego PKB & 3,1 & $-1,8$ & 2,8 & 3,1 & 2,5 & 2,7 \\
\hline
\end{tabular}

Źródło: Opracowanie własne na podstawie danych Banku Światowego.

Tabela 29. Wynik ekonomiczny budżetu państwa jako \% PKB oraz dług publiczny jako \% PKB w RPA w latach 2008-2013

\begin{tabular}{|l|c|c|c|c|c|c|}
\hline & 2008 & 2009 & 2010 & 2011 & 2012 & 2013 \\
\hline Wynik ekonomiczny budżetu państwa jako \% PKB & $-0,6$ & $-2,6$ & $-7,7$ & $-5,3$ & $-4,8$ & $-5,2$ \\
\hline Dług publiczny jako \% PKB (na koniec roku) & 31,6 & 29,7 & 33,2 & 34,1 & 39,4 & 42,5 \\
\hline
\end{tabular}

Źródło: Opracowanie własne na podstawie danych Banku Światowego.

Tabela 30. Dochody budżetowe jako \% PKB oraz wydatki budżetowe jako \% PKB w RPA w latach 2008-2013

\begin{tabular}{|l|c|c|c|c|c|c|}
\hline & 2008 & 2009 & 2010 & 2011 & 2012 & 2013 \\
\hline Dochody budżetowe jako \% PKB & 27,3 & 26,5 & 28,5 & 28,3 & 27,7 & 27,7 \\
\hline Wydatki budżetowe jako \% PKB & 27,9 & 29,2 & 36,3 & 33,6 & 32,5 & 32,9 \\
\hline
\end{tabular}

Źródło: Opracowanie własne na podstawie danych Banku Światowego.

Tabela 31. Tempo zmiany nominalnych dochodów budżetowych oraz nominalnych wydatków budżetowych w RPA w latach 2008-2013

\begin{tabular}{|l|c|c|c|c|c|c|}
\hline & 2008 & 2009 & 2010 & 2011 & 2012 & 2013 \\
\hline Tempo zmiany nominalnych dochodów budżetowych & - & 9,5 & 7,6 & 14,8 & 10,0 & 6,9 \\
\hline Tempo zmiany nominalnych wydatków budżetowych & - & 17,7 & 24,3 & 7,4 & 8,4 & 8,6 \\
\hline
\end{tabular}

Źródło: Opracowanie własne na podstawie danych Banku Światowego.

W Maroku w 2008 r. zanotowano deficyt ekonomiczny budżetu państwa na poziomie 0,3\% PKB. Lata 2009-2012 to czas silnego wzrostu deficytu ekonomicznego budżetu państwa w relacji do $\mathrm{PKB}$. W okresie tym równie istotnymi źródłami pogłębiania się nierównowagi budżetowej były spadek udziału dochodów budżetowych w PKB oraz wzrost wydatków budżetowych w relacji do PKB. Wzrost wydatków budżetowych jako \% PKB dokonywał się w warunkach wzrostu nominalnego PKB, a więc był determinowany wyłącznie przez wzrost nominalnych wydatków budżetowych. 
W latach 2009-2013 dług publiczny Maroka wzrósł z 48,2\% PKB na koniec 2008 r. do 58,9\% PKB na koniec 2013 r.

Tabela 32. Tempo zmiany nominalnego PKB oraz realnego PKB w Maroku w latach 2008-2012

\begin{tabular}{|l|c|c|c|c|c|}
\hline & 2008 & 2009 & 2010 & 2011 & 2012 \\
\hline Tempo zmiany nominalnego PKB & 5,6 & 4,8 & 3,6 & 5,0 & 2,7 \\
\hline Tempo zmiany realnego PKB & 5,4 & 4,9 & 3,2 & 4,3 & 2,7 \\
\hline
\end{tabular}

Źródło: Opracowanie własne na podstawie danych Banku Światowego.

Tabela 33. Wynik ekonomiczny budżetu państwa jako \% PKB oraz dług publiczny jako \% PKB w Maroku w latach 2008-2012

\begin{tabular}{|l|c|c|c|c|c|}
\hline & 2008 & 2009 & 2010 & 2011 & 2012 \\
\hline Wynik ekonomiczny budżetu państwa jako \% PKB & $-0,3$ & $-1,6$ & $-4,2$ & $-6,6$ & $-7,1$ \\
\hline Dług publiczny jako \% PKB (na koniec roku) & 47,3 & 46,9 & 50,3 & 53,7 & 59,6 \\
\hline
\end{tabular}

Źródło: Opracowanie własne na podstawie danych Banku Światowego.

Tabela 34. Dochody budżetowe jako \% PKB oraz wydatki budżetowe jako \% PKB w Maroku w latach 2008-2012

\begin{tabular}{|l|c|c|c|c|c|}
\hline & 2008 & 2009 & 2010 & 2011 & 2012 \\
\hline Dochody budżetowe jako \% PKB & 32,5 & 29,3 & 27,5 & 27,8 & 28,7 \\
\hline Wydatki budżetowe jako \% PKB & 31,8 & 31,1 & 31,9 & 34,5 & 36,1 \\
\hline
\end{tabular}

Źródło: Opracowanie własne na podstawie danych Banku Światowego.

Tabela 35. Tempo zmiany nominalnych dochodów budżetowych oraz nominalnych wydatków budżetowych w Maroku w latach 2008-2012

\begin{tabular}{|l|c|c|c|c|c|}
\hline & 2008 & 2009 & 2010 & 2011 & 2012 \\
\hline Tempo zmiany nominalnych dochodów budżetowych & 21,5 & $-4,3$ & $-1,9$ & 6,1 & 6,5 \\
\hline Tempo zmiany nominalnych wydatków budżetowych & 18,4 & 3,9 & 7,1 & 13,1 & 7,7 \\
\hline
\end{tabular}

Źródło: Opracowanie własne na podstawie danych Banku Światowego.

W Nigerii w 2009 r. budżet państwa zamknął się deficytem ekonomicznym w wysokości 3,2\% PKB. W latach 2010-2012 obserwowano systematyczne zmniejszanie się tego deficytu aż do poziomu 1,3\% PKB w 2012 r. Na koniec 2013 r. dług publiczny Nigerii wyniósł 15,4\% PKB (na koniec 2007 r. 12,8\% PKB).

W Algierii w 2009 r. budżet państwa zamknął się deficytem ekonomicznym w wysokości 4,5\% PKB. W latach 2010-2011 w budżecie państwa odnotowywano już jednak równowagę. Na koniec 2013 r. dług publiczny Algierii wyniósł 13,2\% PKB. 
Na koniec 2013 r. bardzo wysokim (nietypowym dla krajów afrykańskich) długiem publicznym odznaczał się Egipt. Wynosił on $81,1 \%$ PKB. Na podobnym poziomie kształtował się także na koniec 2007 r. W roku 2012 w budżecie państwa w Egipcie zanotowano deficyt ekonomiczny na poziomie 10,6\% PKB.

Z kolei w Angoli w 2009 r. budżet państwa zamknął się deficytem ekonomicznym równym 11,0\% PKB. W latach 2011-2012 notowano już bardzo wysokie ekonomiczne nadwyżki budżetowe. Na koniec 2013 r. dług publiczny wyniósł w tym kraju 29,2\% PKB (na koniec 2007 r. 21,4\% PKB).

W Tunezji w okresie 2009-2010 notowano deficyt ekonomiczny budżetu państwa na poziomie 1,5\% PKB. W latach 2011-2012 deficyt ekonomiczny wzrósł do 5,0\% PKB. Na koniec 2013 r. dług publiczny Tunezji wynosił 51,5\% PKB (na koniec 2007 r. $45,9 \%$ PKB).

Ghana w latach 2009-2011 odznaczała się wysokimi deficytami ekonomicznymi budżetu państwa w relacji do PKB. Na koniec 2013 r. dług publiczny tego kraju wyniósł 53,1\% PKB (na koniec 2007 r. 31,0\% PKB).

Jak pokazuje przedstawiony przegląd, kraje Afryki, z wyjątkiem Egiptu, odznaczają się bardzo niskim bądź niskim poziomem długu publicznego w relacji do PKB.

Tabela 36. Wynik ekonomiczny budżetu państwa jako \% PKB w wybranych krajach Afryki w latach 2009-2012

\begin{tabular}{|l|c|c|c|c|}
\hline \multicolumn{1}{|c|}{ Kraj } & 2009 & 2010 & 2011 & 2012 \\
\hline Algieria & $-4,5$ & 0,4 & $-0,3$ & - \\
\hline Angola & $-11,0$ & 0,9 & 11,4 & 6,7 \\
\hline Ghana & $-5,6$ & $-7,2$ & $-3,9$ & - \\
\hline Nigeria & $-3,2$ & $-2,0$ & $-1,8$ & $-1,3$ \\
\hline Tunezja & $-1,5$ & $-1,4$ & $-3,8$ & $-5,0$ \\
\hline
\end{tabular}

Źródło: Opracowanie własne na podstawie danych Banku Światowego.

\subsection{Sytuacja finansów publicznych w krajach Azji}

W Japonii w latach 2007-2008 w budżecie państwa zanotowano relatywnie niski deficyt ekonomiczny, odpowiednio 2,5\% PKB i 3,0\% PKB. Z kolei lata 2009-2013 to okres ogromnych deficytów ekonomicznych budżetu państwa: w każdym roku deficyt ekonomiczny przekraczał 8,0\% PKB, a w 2013 r. osiągnął nawet 9,2\% PKB. W okresie 2008-2013 dług publiczny Japonii wzrósł z 183,0\% PKB na koniec 2007 r. do $245,0 \%$ PKB na koniec 2013 r. 
W Korei Południowej w latach 2009-2011 budżet państwa zamykał się nadwyżką ekonomiczną. Na koniec 2013 r. dług publiczny tego kraju wyniósł 35,8\% PKB (na koniec 2007 r. 30,7\% PKB).

Z kolei dług publiczny Chin kształtował się na koniec 2013 r. na poziomie $19,6 \%$ PKB (identycznie jak na koniec 2007 r.). W roku 2013 budżet państwa zamknął się w Chinach deficytem ekonomicznym na poziomie $2,1 \%$ PKB.

W Turcji w $2009 \mathrm{r}$. w budżecie państwa zanotowano deficyt ekonomiczny w wysokości 5,8\% PKB. Lata 2010-2012 to w tym kraju okres systematycznej redukcji deficytu ekonomicznego budżetu państwa w relacji do PKB. W roku 2012 deficyt ten wyniósł zaledwie 0,6\% PKB. W latach 2010-2013 zmniejszał się też dług publiczny Turcji. Na koniec 2013 r. wyniósł on 36,7\% PKB, podczas gdy na koniec 2007 r. 39,9\% PKB.

W Indiach w latach 2008-2013 zmniejszył się poziom długu publicznego z 75,5\% na koniec 2007 r. do 66,7\% na koniec 2013 r.

Zmienność poziomu długu publicznego $\mathrm{w}$ innych gospodarkach azjatyckich została przedstawiona w tabeli 38 .

Tabela 37. Wynik ekonomiczny budżetu państwa jako \% PKB w wybranych krajach Azji w latach 2009-2012

\begin{tabular}{|l|c|c|c|c|}
\hline \multicolumn{1}{|c|}{ Kraj } & 2009 & 2010 & 2011 & 2012 \\
\hline Filipiny & $-3,8$ & $-3,5$ & $-1,8$ & $-1,9$ \\
\hline Indie & $-5,4$ & $-3,4$ & $-2,9$ & $-3,8$ \\
\hline Korea Płd. & 0,0 & 1,5 & 1,7 & - \\
\hline Kuwwejt & 19,3 & 18,1 & 27,5 & 27,9 \\
\hline Malezja & $-6,1$ & $-5,2$ & $-4,8$ & $-4,5$ \\
\hline Pakistan & $-4,6$ & $-5,0$ & $-6,4$ & $-8,0$ \\
\hline Singapur & 1,6 & 7,6 & 9,3 & 8,7 \\
\hline Tajlandia & $-3,0$ & $-0,6$ & $-1,1$ & $-2,2$ \\
\hline Turcja & $-5,8$ & $-3,2$ & $-1,1$ & $-0,6$ \\
\hline
\end{tabular}

Źródło: Opracowanie własne na podstawie danych Banku Światowego.

Tabela 38. Dług publiczny jako \% PKB w wybranych krajach Azji na koniec lat 2007 i 2013

\begin{tabular}{|l|c|c|}
\hline \multicolumn{1}{|c|}{ Kraj } & Na koniec 2007 roku & Na koniec 2013 roku \\
\hline Arabia Saudyjska & 18,5 & 5,3 \\
\hline Filipiny & 44,6 & 39,7 \\
\hline Indonezja & 35,1 & 22,2 \\
\hline Irak & 172,9 & 25,5 \\
\hline Iran & 16,6 & 9,3 \\
\hline
\end{tabular}




\begin{tabular}{|l|c|c|}
\hline \multicolumn{1}{|c|}{ Kraj } & Na koniec 2007 roku & Na koniec 2013 roku \\
\hline Katar & 7,4 & 32,5 \\
\hline Kazachstan & 5,9 & 13,0 \\
\hline Kuwejt & 11,8 & 7,1 \\
\hline Malezja & 41,2 & 53,5 \\
\hline Pakistan & 55,9 & 63,0 \\
\hline Singapur & 85,8 & 103,4 \\
\hline Tajlandia & 38,3 & 46,2 \\
\hline Tajwan & 33,3 & 40,9 \\
\hline Wietnam & 44,6 & 50,6 \\
\hline ZEA & 7,8 & 16,4 \\
\hline
\end{tabular}

Źródło: Opracowanie własne na podstawie danych Banku Światowego.

Jak widzimy, w większości zaprezentowanych państw azjatyckich koniec $2013 \mathrm{r}$. zamykał się znacznie niższym długiem publicznym w porównaniu ze średnim długiem publicznym krajów Unii Europejskiej. Ponadto w większości państw azjatyckich, należących do grupy 60 największych gospodarek świata, dług publiczny jako \% PKB w latach 2008-2013 zwiększył się nieznacznie, a w niektórych nawet się obniżył.

Przedstawiony przegląd świata pod kątem stanu finansów publicznych poszczególnych krajów pokazuje, że nie jest prawdziwa opinia (wygłaszana często zwłaszcza przez europejskich polityków gospodarczych), iż po 2007 r., w okresie światowego kryzysu ekonomicznego nie można było uniknąć kryzysu finansów publicznych, a więc wysokich deficytów budżetowych i istotnego wzrostu długu publicznego. Niskie tempo wzrostu gospodarczego czy nawet recesja gospodarcza nie musi automatycznie prowadzić do pogorszenia sytuacji finansów publicznych i poprzez to tworzyć dodatkowy czynnik negatywnie oddziaływający na tempo wzrostu realnej produkcji. Są przykłady krajów, które mimo wyjątkowo niskiego tempa wzrostu gospodarczego $\mathrm{w}$ ostatnich latach uniknęły znacznego wzrostu długu publicznego w relacji do PKB, ale są i takie kraje, które odznaczały się relatywnie wysokim wzrostem realnego PKB, a mimo to doprowadziły do istotnego wzrostu udziału długu publicznego w PKB. 


\section{Economic and legal perspectives on public debt. Changes in public debt in selected non-European economies after 2007 in comparison with the EU member states}

The two main aims of the text were comparative analysis of several legal methodologies for defining public debt developed by international organizations and presenting the Polish legal methodology of calculating public debt while pointing out to the differences between methodologies. Presentation of the concept of the budget deficit and public debt in economic theory served as introduction to the description of legal approach to public debt. The second part of the study examines the economic volatility of the state budget deficit and public debt in selected non-European economies after 2007. The analysis was carried out on a group of sixty-largest economies in the world by GDP at market prices by purchasing power parity. The state of public finance of non - European economies is shown in comparison with the state of EU public finance.

Keywords: budget deficit, public debt, legal methodologies of calculating public debt

\section{La dette publique - la perspective économique et la perspective juridique. Les changements dans la dette publique dans les économies non-européennes sélectionnées après 2007 en comparaison avec les Etats membres de l'UE}

Les deux objectifs du texte sont: l'analyse comparative de plusieurs méthodes juridiques pour définir la dette publique élaborées par les organisations internationales et la présentation la méthode juridique polonaise pour calculer la dette publique tout en soulignant les différences entre les méthodes. La présentation du concept du déficit budgétaire et de la dette publique dans la théorie économique est l'introduction à la description de l'approche légale de la dette publique. La deuxième partie de l'étude examine la volatilité économique du déficit budgétaire de l'Etat et de la dette publique dans les économies non-européennes sélectionnées après 2007. L'analyse comprend soixante des plus grandes économies du monde par le PIB (prix de marché, PPA). L'état des finances publiques des économies non-européennes est présenté en comparaison avec l'état des finances publiques de l'UE.

Mots-clés: le déficit budgétaire, la dette publique, les méthodes juridiques de calcul de la dette publique 


\section{Экономические и юридические подходы к понятию государственного долга. Изменения государственного долга в избранных неевропейских странах после 2007 года по сравнению со странами EC}

В статье автор преследует две основные цели. Первой из них является сравнительный анализ избранных методологий по юридическому определению государственного долга, разработанных международными организациями. В исследовании также представлена польская методология расчета государственного долга, указывая на разницы по отношению к международным методологиям. Введением, к презентации юридического подхода к понятию государственного долга, послужило указание концепций бюджетного дефицита и государственного долга в экономической теории. Во второй части исследования рассматриваются изменения дефицита государственного бюджета и государственного долга в избранных неевропейских странах после 2007 года. Подобранные страны находятся в группе шестидесяти крупнейших экономик мира по объёму ВВП в рыночных ценах по ППС. Положение государственных финансов неевропейских стран в последние годы указано на фоне состояния государственных финансов стран Европейского союза.

Ключевые слова: государственный долг, методологии по юридическому определению государственного долга 